\title{
PROSES PENGELOLAHAN MENINGKATKAN AKTIVITAS HIPOLIPIDEMIK JAMUR TIRAM (PLEUROTUS OSTREATUS) PADA TIKUS (RATTUS NORVEGICUS) SPRGUE-DAWLEY HIPERKOLESTEROL
}

\author{
Eni Harmayani dan Deera Army Pramana \\ Program Studi Bioteknologi \\ Sekolah Pascasarjana Universitas Gadjah Mada \\ Sri Anggrahini dan Sutikarini \\ Program Pascasarjana Ilmu dan Teknologi Pangan \\ Fakultas Teknologi Pertanian \\ Universitas Gadjah Mada
}

\begin{abstract}
Oyster mushroom is considered to have hypocholesterolemic and hypolipidemic activities. Therefore, it is classified as functional food. Prior to serving and consumption, oyster mushroom can be processed in various ways. This research studied the effect of three kinds of processing commonly used in cooking oyster mushroom; boiling, frying, and roasting. Thirty Sprague-Dawley male rats, 8 weeks old, were acclimated to laboratory condition, and then induced with high lipid diet. The rats were divided into five experiment groups; high-lipid diet (K), high-lipid diet + raw oyster mushroom $(M)$, high-lipid diet + fried oyster mushroom $(G)$, high-lipid diet + roasted oyster mushroom $(P)$, and high-lipid diet + boiled oyster mushroom $(R)$. Blood samples were obtained from orbital plexus after acclimation, hypercholesterolemic induction, and 21 days of feeding. The blood serum was examined for total cholesterol (TC), triglyceride (TG), low-density lipoprotein cholesterol (LDL-c), dan high-density lipoprotein cholesterol (HDL-c). The result showed that cooked oyster mushroom had better hypocholesterolemic and hypolipidemic activity than raw oyster mushroom. Among the three, the roasted oyster mushroom reduced the total cholesterol the most, while boiled oyster mushroom reduced triglyceride the most.
\end{abstract}

Keyword: Oyster mushroom (Pleurotus ostreatus), Cholesterol, Food processing, hypolipidemic, Hypocholesterolemic. 
JURNAL TEKKNOSAINS

VOLUME 2

No. 1, 22 Desember 2012

Halaman 1-70

\title{
PROSES PENGELOLAHAN MENINGKATKAN AKTIVITAS HIPOLIPIDEMIK JAMUR TIRAM (PLEUROTUS OSTREATUS) PADA TIKUS (RATTUS NORVEGICUS) SPRGUE-DAWLEY HIPERKOLESTEROL
}

\author{
Eni Harmayani dan Deera Army Pramana \\ Program Studi Bioteknologi \\ Sekolah Pascasarjana Universitas Gadjah Mada \\ Sri Anggrahini dan Sutikarini \\ Program Pascasarjana Ilmu dan Teknologi Pangan \\ Fakultas Teknologi Pertanian \\ Universitas Gadjah Mada
}

\begin{abstract}
ABSTRAK
Jamur tiram dikenal memiliki aktivitas hipokolesterolemik dan hipolipidemik sehingga dapat dikategorikan dalam bahan pangan fungsional. Sebagai bahan pangan, jamur tiram harus diolah terlebih dahulu sebelum dikonsumsi. Penelitian ini bertujuan untuk mengetahui pengaruh tiga jenis proses pengolahan jamur tiram yang umum dilakukan, yaitu perebusan, penggorengan, dan pemanggangan, terhadap aktivitas hipokolesterolmik jamur tiram. Tiga puluh ekor tikus jantan galur Sprague-Dawley berumur 8 minggu diadaptasikan terhadap kondisi laboratorium, lalu diinduksi dengan diet tinggi lemak. Tikus dibagi secara acak ke dalam lima kelompok perlakuan; diet tinggi lemak $(\mathrm{K})$, diet tinggi lemak + jamur tiram mentah $(\mathrm{M})$, diet tinggi lemak + jamur tiram goreng $(\mathrm{G})$, diet tinggi lemak + jamur tiram panggang $(\mathrm{P})$, dan diet tinggi lemak + jamur tiram rebus (R). Setelah masa aklimasi, induksi, dan 21 hari perlakuan, diambil sampel darah dari sinus orbital. Pengukuran kadar total kolesterol (TC), trigliserida (TG), kolesterol low-density lipoprotein (LDL-c), dan kolesterol high-density lipoprotein (HDL-c) dilakukan terhadap serum darah. Hasil penelitian menunjukkan bahwa jamur tiram yang telah diolah memberikan efek hipokolesterolemik dan hipolipidemik yang lebih baik dibandingkan dengan jamur mentah. Di antara ketiga cara pengolahan, pemanggangan merupakan cara pengolahan yang paling baik dalam menurunkan kolesterol total, sedangkan perebusan paling baik dalam menurunkan trigliserida darah.
\end{abstract}

Kata Kunci: jamur tiram (Pleurotus ostreatus), kolesterol, pengolahan, hipolipidemik, hipokolesterolemik. 


\section{PENGANTAR}

Jamur tiram telah dikenal masyarakat sebagai bahan pangan sejak lama. Jamur tiram memilikikandungangiziyang baikyaitukadar protein dan serat tinggi, tetapi rendah lemak (Regula \& Siwulski, 2007). Di samping itu, beberapa penelitian menunjukkan diet jamur tiram memiliki aktivitas hipokolesterolemik dengan menurunkan kadar lipid darah, yaitu total kolesterol, trigliserida, dan rasio LDL/ HDL. Jamur tiram mampu meningkatkan ekskresi lipid dan kolesterol melalui feses pada tikus hiperkolesterolemik (Alam, dkk: 2009). Pemberian jamur tiram mampu menurunkan lipid aterogenik, seperti LDL. LDL merupakan lipid aterogenik yang jika teroksidasi akan meningkatkan resiko terjadinya aterosklerosis dan penyakit jantung koroner (Hossain, dkk: 2003). Penelitian ini bertujuan untuk mempelajari pengaruh cara pengolahan (pemanggangan, perebusan, dan penggorengan) penurunan kandungan kolesterol tikus percobaan yang diberi diet olahan jamur tiram.

\section{Bahan dan Metode Percobaan Hewan Percobaan}

Tiga puluh ekor tikus putih (Rattus norvegicus L.) jantan sehat galur Sprague Dawley (SD) berumur 8 minggu dengan rerata berat badan $183,46 \pm 25,43 \mathrm{~g}$ dibeli dari Unit Pengembangan Hewan Percobaan (UPHP) Universitas Gadjah Mada Yogyakarta. Pemeliharaan tikus dilakukan di Ruang Pemeliharaan Hewan Coba Laboratorium Pusat Studi Bioteknologi dalam kondisi suhu, pencahayaan, dan kelembaban alami. Evaluasi ethical clearance untuk penggunaan tikus dalam penelitian ini dilakukan oleh Komisi Etik Fakultas Kedokteran Universitas Gadjah Mada.

Tikus dibagi ke dalam lima kelompok perlakuan dengan Rancangan Acak Lengkap, masing-masing terdiri atas enam ekor. Kemudian, tikus diadaptasikan dengan kondisi lingkungan dan pakan AIN-93 selama 7 hari. Induksi hiperkolesterol dilakukan selama 7 hari berikutnya, dengan memberikan pakan tinggi lemak yang dimodifikasi dari AIN-93. Kelompok perlakuan pertama adalah kontrol, dan diberi diet tinggi lemak sampai akhir penelitian. Kelompok kedua hingga kelima diberi diet tinggi lemak dengan campuran tepung jamur tiram selama 21 hari. Kelompok kedua segar diberi diet tinggi lemak dan jamur tiram mentah (tanpa pengolahan). Kelompok ketiga diberi diet tinggi lemak dan jamur tiram goreng. Kelompok keempat diberi diet tinggi lemak dan jamur tiram panggang. Kelompok kelima diberi diet tinggi lemak dan jamur tiram rebus. Pengambilan darah dilakukan setelah masa adaptasi, setelah induksi hiperkolesterol, dan setelah pemberian perlakuan. Sebelum diambil darahnya, tikus dipuasakan semalam. Pengambilan darah dilakukan dari sinus orbitalis sebanyak kira-kira 1,5 mL.

\section{Jamur Tiram}

Jamur tiram putih segar diperoleh dari petani jamur, Bapak Erik, di Jl.Kaliurang Km.16, Sleman. Jamur tiram yang akan digunakan untuk campuran pakan terlebih dahulu diblansir (blanching) dengan perebusan selama 30 menit. Selanjutnya, jamur yang telah diblansir tersebut disuwir-suwir dan diberi perlakuan pengolahan. Penggorengan dilakukan dengan dip frying menggunakan minyak goreng Sania pada suhu $170^{\circ} \mathrm{C}$, dengan perbandingan $400 \mathrm{~g}$ jamur dalam 4 liter minyak. Pemanggangan dilakukan dengan oven gas pada suhu $190^{\circ} \mathrm{C}, 20-30$ tusuk dalam satu kali panggang. Perebusan dengan air dilakukan pada suhu $100^{\circ} \mathrm{C}$, dengan perbandingan $700 \mathrm{~g}$ jamur dalam 6 liter air. Masing-masing pengolahan selama 10 menit. Untuk pembuatan tepung jamur mentah, jamur tiram segar tidak diberi perlakuan blanching ataupun pengolahan. Jamur tiram tersebut kemudian dikeringkan dalam cabinet dryer bersuhu $50^{\circ} \mathrm{C}$ selama 25 jam. Setelah kering, jamur digiling dengan blender kering, dan ditapis dengan saringan 40 mesh. 


\section{Pakan}

Pembuatan pakan tikus dilakukan dengan mengacu standar AIN-93 (Reeves et al.,1993). Pakan tinggi lemak yang digunakan dalam penelitian ini dibuat dengan mengganti sebagian kalori 180 gram pati jagung (corn starch) dengan lemak sapi (tallow) per 1000 gram (Garg, 1994). Pakan tinggi lemak dimodifikasi untuk pembuatan pakan jamur dengan formulasi isoserat, yaitu dengan mengganti 50 gram serat dari CMC dengan 50 gram serat dari tepung jamur. Komposisi setiap kilogram pakan perlakuan diformulasikan sebagaimana tercantum dalam Tabel 1.

Tabel 1. Komposisi per $1000 \mathrm{~g}$ pakan tikus yang digunakan selama penelitia

\begin{tabular}{|c|c|c|c|c|c|c|c|}
\hline No. & Bahan & AIN-93 & $\begin{array}{l}\text { Pakan tinggi } \\
\text { lemak (HL) }\end{array}$ & $\begin{array}{c}\mathrm{HL}+ \\
\text { jamur } \\
\text { mentah }\end{array}$ & $\begin{array}{l}\text { HL + } \\
\text { jamur } \\
\text { goreng }\end{array}$ & $\begin{array}{l}\mathrm{HL}+ \\
\text { jamur } \\
\text { rebus }\end{array}$ & $\begin{array}{c}\mathrm{HL}+ \\
\text { jamur } \\
\text { panggang }\end{array}$ \\
\hline 1 & Pati jagung (maizena) & 620,7 & 440,7 & 402,8 & 404,8 & 420,0 & 420,6 \\
\hline 2 & Kasein (protein) & 140 & 140 & 110,5 & 123,9 & 125,0 & 122,9 \\
\hline 3 & Sukrosa (karbohidrat) & 100 & 100 & 100,0 & 100,0 & 100,0 & 100,0 \\
\hline 4 & Minyak kedelai (lemak) & 40 & 40 & 37,7 & 0,0 & 37,9 & 37,6 \\
\hline 5 & CMC (serat) & 50 & 50 & 0,0 & 0,0 & 0,0 & 0,0 \\
\hline 6 & Campuran mineral & 35 & 35 & 23,6 & 31,8 & 32,1 & 31,6 \\
\hline 7 & Campuran vitamin & 10 & 10 & 10,0 & 10,0 & 10,0 & 10,0 \\
\hline 8 & L-sistin & 1,8 & 1,8 & 1,8 & 1,8 & 1,8 & 1,8 \\
\hline 9 & Kolin bitartrat & 2,5 & 2,5 & 2,5 & 2,5 & 2,5 & 2,5 \\
\hline 10 & TBHQ & 0,008 & 0,04 & 0,04 & 0,04 & 0,04 & 0,04 \\
\hline 11 & Lemak sapi (tallow) & 0 & 180 & 180,0 & 155,2 & 180,0 & 180,0 \\
\hline \multirow[t]{2}{*}{12} & tepung jamur & 0 & 0 & 146,8 & 177,4 & 99,2 & 101,4 \\
\hline & TOTAL & 1000,008 & 1000,04 & 1015,8 & 1007,3 & 1008,5 & 1008,5 \\
\hline
\end{tabular}

\section{Bioassay}

Analisis total kolesterol dilakukan menggunakan metode CHOD-PAP (Deeg, dkk: 1983 dan Artiss, dkk: 1997). LDL ditentukan dengan metode presipitasi, kemudian dilanjutkan secara enzimatis dengan metode CHOD-PAP (Favier, dkk: 1995). HDL ditentukan dengan metode presipitasi, kemudian dilanjutkan secara enzimatis dengan metode CHOD-PAP (Eckel, dkk: 1977). Analisis trigliserida dilakukan dengan metode GPO-PAP (Cobbold, dkk: 2002).

\section{PEMBAHASAN}

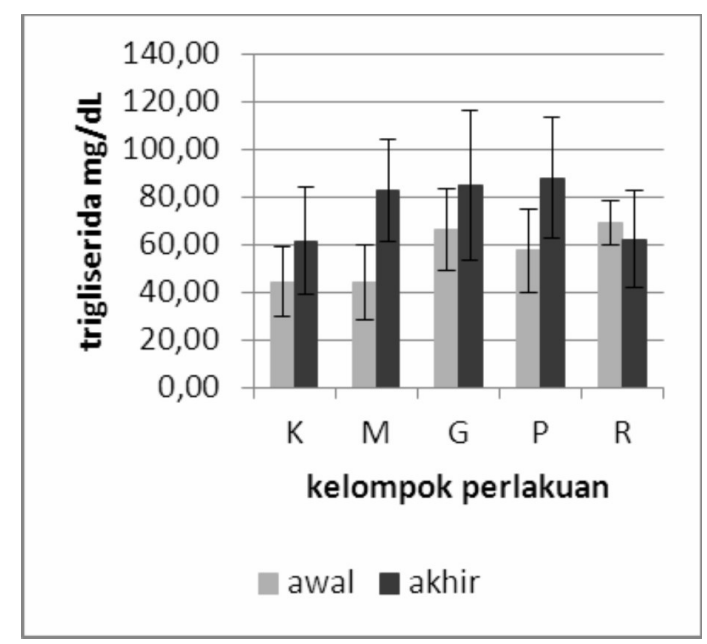




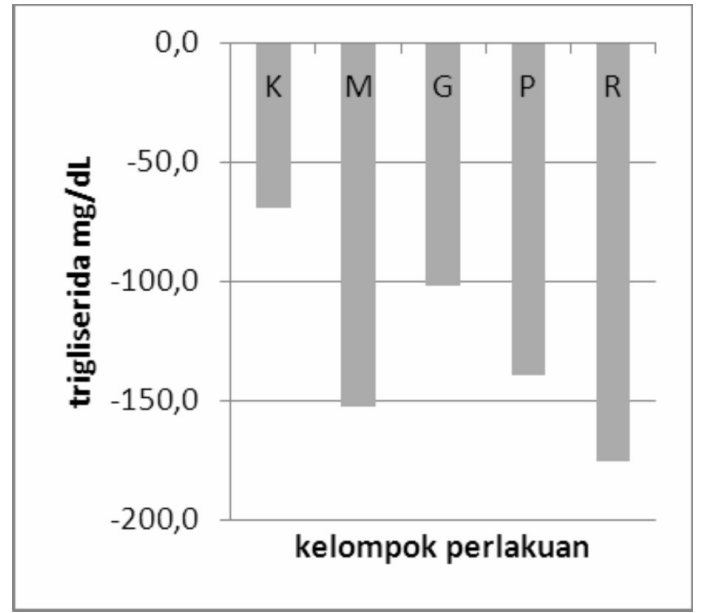

Gambar 1. Perubahan Total Kolesterol dan Kolesterol LDL Setelah Perlakuan Pakan Jamur Tiram.

Keterangan: K (perlakuan pakan tinggi lemak), $M$ (perlakuan pakan tinggi lemak + jamur tiram mentah), $G$ (perlakuan pakan tinggi lemak + jamur tiram goreng), $P$ (perlakuan pakan tinggi lemak + jamur tiram panggang), (perlakuan pakan tinggi lemak + jamur tiram rebus).

Pada penelitian ini bahwa pemberian jamur tiram yang telah diolah terhadap tikus Sprague Dawley melalui diet, menunjukkan sedikit perbedaan dari penelitian-penelitian di atas. Jamur tiram mentah tidak menunjukkan adanya penurunan total kolesterol. Kolesterol LDL pada kelompok M mengalami penurunan, tetapi tidak signifikan terhadap kontrol (Gambar 1). Jamur yang telah diolah, baik digoreng, direbus, maupun dipanggang, mampu menurunkan total kolesterol, dan kolesterol LDL secara lebih baik, jika dibandingkan dengan jamur mentah. Tingkat penurunan total kolesterol dan kolesterol LDL oleh ketiga jenis perlakuan tersebut tidak berbeda secara nyata. Pengolahan dengan cara dipanggang sedikit lebih baik dalam menurunkan total kolesterol, sedangkan penggorengan sedikit lebih baik dalam menurunkan kolesterol LDL.
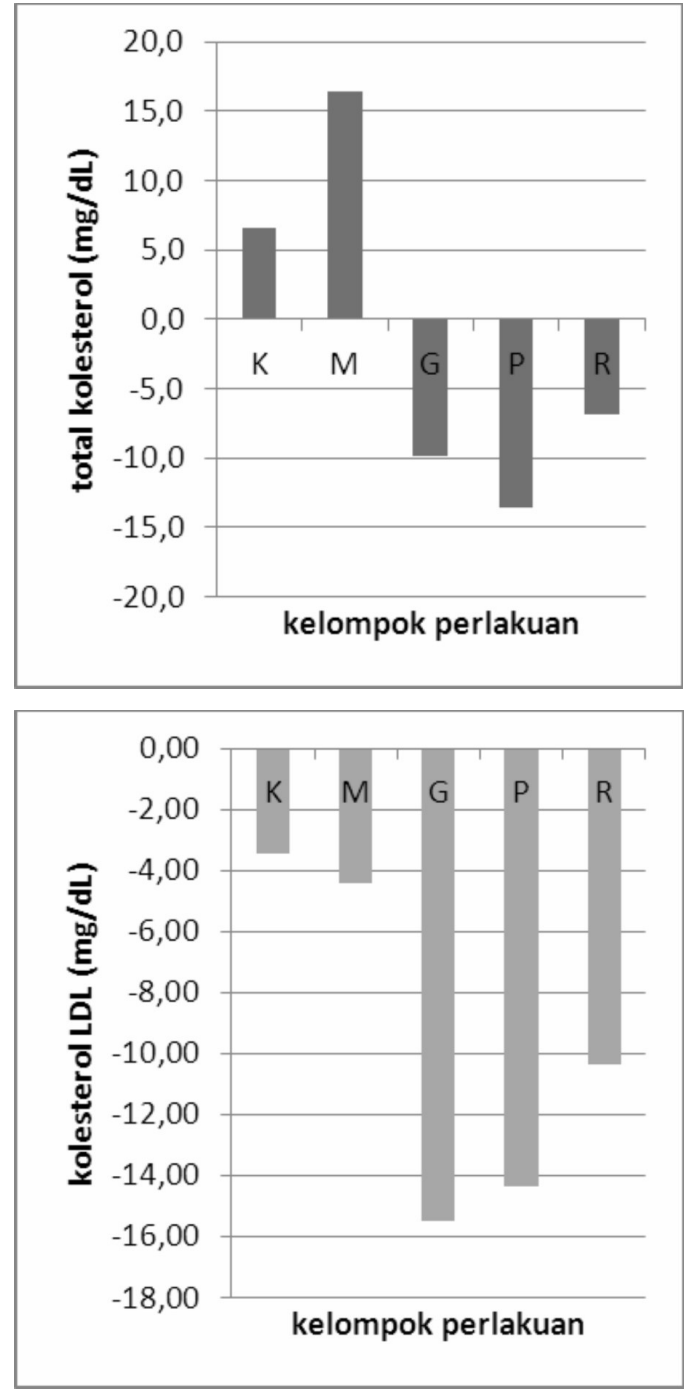

Gambar 2. Perubahan Trigliserida Setelah Perlakuan Pakan Jamur dengan Pakan Jamur Tiram.

Keterangan: K (perlakuan pakan tinggi lemak), M (perlakuan pakan tinggi lemak + jamur tiram mentah), G (perlakuan pakan tinggi lemak + jamur tiram goreng), $P$ (perlakuan pakan tinggi lemak + jamur tiram panggang), (perlakuan pakan tinggi lemak + jamur tiram rebus).

Kadar trigliserida dalam serum darah tikus mengalami penurunan oleh pemberian jamur tiram, baik yang mentah maupun yang telah mengalami pengolahan. Di antara 
perlakuan pakan jamur tiram yang diolah, kelompok $\mathrm{R}$ yang diberi jamur tiram rebus mengalami penurunan trigliserida paling tinggi dibandingkan kelompok $\mathrm{M}$ dan dengan kelompok lain (P\&G). Kelompok $G$ mengalami penurunan kadar trigliserida paling sedikit.

Banyak penelitian telah menunjukkan efek hipokolesterolemik dan hipolipidemik yang dimiliki oleh jamur tiram. Alam dalam penelitiannya bahwa penambahan tepung jamur tiram sebanyak $5 \%$ dalam pakan dapat menurunkan kadar lipid darah, yaitu total kolesterol, trigliserida, dan rasio kolesterol LDL/HDL pada tikus galur Long Evans hiperkolesterolemik (Alam, dkk: 2009). Hasil yang serupa ditunjukkan pula oleh penelitan sebelumnya oleh(Hossain, dkk: 2003). Pemberian jamur tiram terhadap tikus galur Sprague Dawley hiperkolesterolemik juga mampu menurunkan tingkat total kolesterol, trigliserida, dan kolesterol LDL (Alam, dkk: 2011).

Berbeda dari penelitian sebelumnya, jamur tiram yang tidak diolah hanya memberikan efek hipolipidemik, tetapi tidak memiliki aktivitas hipokolesterolemik. Jamur tiram yang telah diolah, memiliki kedua aktivitas tersebut. Pengolahan dengan cara perebusan, meskipun dalam penurunan kolesterol tidak setinggi penggorengan dan pemanggangan merupakan yang paling baik dalam menurunkan kadar trigliserida darah.

Mekanisme penurunan kolesterol dan lipid darah oleh jamur tiram meliputi penghambatan enzim pensintesis kolesterol, peningkatan ekskresi kolesterol, dan peningkatan ekskresi garam empedu. Statin dan $\beta$-glucan pada jamur tiram merupakan molekul yang berkontribusi dalam aktivitas hipokolesterolemik jamur tiram. Statin merupakan molekul yang memiliki kemiripan struktur dengan kolesterol, sehingga mampu menjadi inhibitor aktivitas enzim. $\beta$-glucan merupakan serat pangan yang mampu mengikat kolesterol dan garam empedu untuk kemudian diekskresikan dalam feses (Guillamon, dkk: 2010).
Peningkatan aktivitas hipokolesterolemik dan hipolipidemik jamur tiram pascapengolahan kemungkinan berkorelasi dengan perubahan komposisi serat pangan akibat proses pemasakan yang melibatkan pemanasan. Pemanasan dalam proses pengolahan juga akan berpengaruh terhadap karakteristik serat pangan dalam bahan makanan (Kahlon, dkk: 2007). Pemanggangan dapat menurunkan perbandingan $\beta$-glucan yang larut dan tak larut pada barley (Sharma, dkk: 2011). Penelitian lebih lanjut diperlukan untuk mempelajari lebih jauh mengenai mekanisme penurunan kolesterol yang terpengaruh oleh proses pengolahan.

\section{SIMPULAN}

Jamur tiram yang telah diolah memberikan efek hipokolesterolemik dan hipolipidemik yang lebih baik dibandingkan dengan jamur mentah. Di antara ketiga cara pengolahan, pemanggangan merupakan cara pengolahan yang paling baik dalam menurunkan kolesterol total, sedangkan perebusan paling baik dalam menurunkan trigliserida darah.

\section{DAFTAR PUSTAKA}

Alam, N., R. Amin, A. Khan, dkk, 2009, "Comparative effects of oyster mushrooms on lipid profile, liver and kidney function in hypercholesterolaemic rats", Mycobiology, vol.37(1), pp.37-42.

Alam, N., K.N. Young, T.S. Lee, and U. Y. Lee, 2011, "Hypolipidemic activities of dietary Pleuratus ostreatus in hypercolesterolemic rats, Mycobiology", vol.39(1), pp.45-51.

Hossain, S., M. Hashimoto, E.K. Choudhury, dkk, 2003," Dietary mushroom (Pleurotus ostreatus) ameliorates atherogenic lipid in hypercholesterolaemic rats, Clinical 
and Experimental Pharmacology and Physiology", vol.30, pp.470-475.

Cobbold, C.A., J.A. Sherratt, and S.R.J. Maxwell, 2002, "Lipoprotein oxidation and Its Significance for Atherosclerosis: Mathematical Approach", Bulletin of Mathematical Biology, 64:65-95.

Eckel, W., P. Stone, S. Ellis, and Cowell, 1997, Cholesterol Determination in HighDensity Lipoprotein Separated by Three Different Methods, Clin. Chem, 23:882-884.

Favier, A.E., J. Cadet, B. Kalyanaraman, M. Fontecave, and J.L. Pierre,1995, "Analysis of Free Radicals in Biological System", Birkhauser Verlag Basel, Switzerland.

Garg, M.L, 1994, “Metabolic fate of cholesterol in rats fed diets containing canola oil or safflower
oil",Proc.Nutr.Soc.Aust., vol.18, pp.83.

Kahlon, T.S., M.M. Chiu and M.H. Chapman, 2007, "Steam cooking significantly improves in vitro bile acid binding of beets, eggplant, asparagus, carrots, green beans, and cauliflower", Nutrition Research, vol.27, pp.750-755.

Reeves, P.G., F.H. Nielsen \& G.C. Fahey, 1993, "AIN-93 purified diets for laboratory rodens: final report of the American Institute of Nutrition Adhoc Writing Committee on the reformulation of the AIN76A rodent diet".J.Nutr., vol.123, pp.1939-1951.

Sharma, P. H.S. Gujral, and C.M. Rosell, 2011, "Effects of roasting on barley $\beta$-glucan, thermal, textural, and pasting properties.Journal of Cereal Science", vol.53, pp.25-30. 